\title{
EKSISTENSI EKONOMI ISLAM (STUDI TENTANG PERKEMBANGAN PERBANKAN SYARIAH DI INDONESIA)
}

\author{
Moh. Indra Bangsawan \\ Fakultas Hukum, Universitas Muhammadiyah Surakarta, Indonesia \\ mibsambi@gmail.com
}

\begin{abstract}
Abstrak
$\mathrm{P}$ erbankan memiliki peran penting dalam pembangunan dan menunjang ekonomi negara, terutama setelah diundangkannya Undang-Undang Nomor 10 Tahun 1998 Tentang Perbankan. Ekonomi Islam di Indonesia saat ini sudah mulai dikenal dan disetujui oleh masyarakat, mengingat menjamurnya bank-bank berbasis Islam menjadikan masyarakat mengerti sistem-sistem dalam ekonomi Islam. Berdirinya Islamic Development Bank (IDB) pada tahun 1975 memicu berdirinya bank Islam diseluruh dunia termasuk Indonesia. Lahirnya Undang-Undang Nomor 21 Tahun 2008 Tentang Perbankan Syariah adalah jaminan bagi eksistensi dan perlindungan hukum bagi perbankan syariah setelah satu dekade terakhir keberadaannya yang hanya mengatur salah satu prinsip bagi hasil yang tidak secara definitif dan komprehensif mengatur aktifitas bank berdasarkan prinsip syariah. Berdasarkan data dari Otoritas Jasa Keuangan Juni 2015, jumlah kantor perbankan syariah mencapai puncaknya pada tahun 2013 yaitu sebanyak 2.990 dan mengalami trend penurunan pada tahun 2015 menjadi 2.881. Oleh karena itu, upaya untuk mengenalkan ekonomi Islam dan peran ekonomi Islam di Indonesia perlu terus ditingkatkan demi menunjang perkembangan ekonomi Islam dalam kehidupan masyarakat. Prediktabilitas Hukum harus mempunyai kemampuan untuk memberikan gambaran pasti di masa depan mengenai eksistensi perbankan syariah atau hubungan-hubungan yang dilakukan pada masa sekarang untuk mengembangkan eksistensi ekonomi syariah.
\end{abstract}

Kata Kunci: Eksistensi Ekonomi Islam, Perbankan Syariah, Prediktabilitas Hukum

\section{PENDAHULUAN}

Secara konseptual, industri keuangan syariah memang sesuai dengan tuntutan perkembangan zaman serta sudah menjadi kewajiban sejarahnya untuk lahir dan tumbuh menjadi sistem keuangan yang alternatif-solutif. Untuk merealisasikan hal ini bukanlah hal yang mudah, banyak tantangan dan rintangan yang harus di hadapi oleh industri keuangan syariah ke depan nanti. Industri keuangan syariah baik bank maupun non-bank saat ini masih dalam tahap awal evolusinya. Walaupun tingkat pertumbuhannya begitu cepat, sejauh ini baru menempati ceruk kecil (small niche) di sektor finansial di negeri-negeri muslim, apalagi disektor keuangan internasional. Meskipun terdapat sejumlah kesulitan, gerakan Islamisasi perbankan berjalan dengan baik. Kemajuan yang dicapai selama seperempat abad terakhir ini menunjukan hasil yang menggembirakan. ${ }^{1}$ Bank Syariah sampai pada Tahun 2015 telah mengalami perkembangan yang pesat. Secara kuantitatif, perkembangan bank syariah tersebut dapat dilihat dari jumlah Bank yang melaksanakan kegiatan usaha berdasarakan prinsip syariah dan dari sisi volume usaha. Sampai dengan Tahun 2015 terdapat 12 (dua belas) Bank Umum Syariah (BUS), 22 Unit Usaha Syariah (UUS) dan 161 Bank

1 Nurhisam Luqman, 2016, "Kepatuhan Syariah (Sharia Compliance) Dalam Industri Keuangan Syariah", Jurnal Hukum IUS QUIA IUSTUM, Vol. 23 No.1, Hlm. 78. 
Pembiayaan Rakyat Syariah (BPRS). Secara keseluruhan jaringan kantor Bank Umum Syariah dan Unit Usaha Syariah berjumlah 2.881 Kantor. (Otoritas Jasa Keungan, Juni 2015)

Indonesia sebagai negara kepulauan dengan populasi 237 juta orang mencapai pertumbuhan rata-rata ekonomi 5,9\% selama tahun 2008-2014. ${ }^{2}$ Pada Bulan September Tahun 2015, pemerintah Indonesia telah membuat 12 paket kebijakan ekonomi. Rangkaian paket kebijakan ekonomi tersebut bertujuan untuk menggairahkan kembali perekonomian di Indonesia. Beberapa paket kebijakan dibuat antara lain untuk menyederhanakan birokrasi, menghapus peraturan yang menghambat, menurunkan tarif, menyesuaikan dengan praktik internasional, serta memberikan insentif kepada UMKM. Sehingga diharapkan pertumbuhan ekonomi tahun 2017 diperkirakan mencapai 5,3 persen, mengingat Indonesia adalah salah satu pengguna internet terbesar di dunia, mencapai 93,4 juta orang dan pengguna telepon pintar (smartphone) mencapai 71 juta orang. ${ }^{3}$ Peranan agama di Indonesia memiliki andil yang sangat penting dalam kehidupan bermasyarakat. Hal ini dinyatakan secara jelas dalam Pancasila sebagai ideologi bangsa Indonesia sila pertama "Ketuhanan Yang Maha Esa". Peranan agama sehubungan dengan perkembangan kehidupan manusia, Djatmoko tidak ragu-ragu menyatakan agama merupakan faktor utama yang berperan dalam mewujudkan pola-pola persepsi dunia bagi manusia persepsi-persepsi itu ikut mempengaruhi perkembangan dunia dan jalannya sejarah. Sebaliknya sejarah juga melaksanakan perubahan dan penyesuaian terus-menerus terhadap pola-pola persepsi tadi, utamanya di lingkungan masyarakat yang sedang berubah dengan pesat. Tentunya, persepsi itu ada relevansinya dengan aktivitas keduniaan yang dimotivasi oleh sistem keyakinan agama. ${ }^{4}$ Perkembangan perbankan syariah di Indonesia diawali dengan pengharapan masyarakat muslim Indonesia di tahun 1970-an untuk dapat melakukan transaksi yang berbasis syariah, sejak di beberapa negara lain yang mayoritas penduduknya beragama Islam telah mendirikan perbankan yang berbasis syariah. Majlis Tarjih Muhammadiyah telah mengambil keputusan mengenai hukum perbankan (1968 \& 1972) yang pada pokoknya menentukan bahwa riba ${ }^{5}$ pada hukumnya adalah haram dengan nash sharih al-Quran dan asSunnah, serta menyarankan kepada PP Muhammadiyah untuk terwujudnya konsepsi sistem perekonomian, khusunya lembaga perbankan, yang sesuai dengan kaidah Islam. ${ }^{6}$

Para ulama melaksanakan kesepakatan bersama dalam mewujudkan bank ${ }^{7}$ yang berbasis non ribawi di Indonesia, yakni dengan diselenggarakannya Lokakarya Bunga Bank dan Perbankan oleh Majelis Ulama Indonesia pada tanggal 18 - 20 Agustus 1990 di Bogor. Hasil Lokakarya tersebut ditindaklanjuti dalam Musyawarah Nasional IV Majelis Ulama Indonesia yang berlangsung di

2 Kementerian koordinator bidang perekonomian, 2013, “Pertemuan World Economic Leaders" (online), https:// www.ekon.go.id/berita/print/pertemuan-world-economic.1366.html, diakses pada tanggal 20 November 2016)

3 Kementerian koordinator bidang perekonomian, 2013, "Paket Kebijakan Ekonomi XIV” (online), (http://www. ekon.go.id/ekliping/view/paket-kebijakan-ekonomi-xiv.2862.html, diakses pada tanggal 20 November 2016)

4 Asifudin Ahmad Janan. 2004, "Etos Kerja Islami”, Surakarta ; Muhammadiyah Press, Hlm.4

5 Asal makna "riba" menurut bahasa Arab ialah lebih (bertambah). Adapun yang dimaksud disini menurut istilah syara' adalah akad yang terjadi dengan penukaran yang tertentu, tidak diketahui sama atau tidaknya menurut aturan syara' atau terlambat menerimanya. Rasjid Sulaiman, 2013, "Fiqih Islam”, Bandung ; Sinar Baru Algesindo, Hlm. 290

6 Jundian, 2009, "Pengaturan Hukum Perbankan Syari'ah di Indonesia”, Malang ; UIN-Malang Press, Hlm. 20

7 Adapun tentang pendirian bank, sudah sering dibicarakan oleh beberapa orang Islam terkemuka di Indonesia dengan jalan pidato maupun di surat-surat kabar. Tentang hal ini hendaknya diadakan permusyawaratan dari dua golongan: 1. Alim ulama (ahli agama) yang betul-betul memikirkan kepentingan agama dan masyarakat. 2. Pihak ahli ekonomi yang benar-benar mengetahui segala seluk beluk bank dan Perdagangan. Permusyawaratan kedua kaum cerdik pandai itu tentu akan didasarkan atas keadaan dari kemaslahatan masyarakat dengan tidak menyampingkan pokok-pokok agama Islam. Dengan permusyawaratan itu mereka dapat memutuskan bahwa pendirian bank dapat dilakukan dengan cara yang tidak termasuk golongan riba, atau barangkali memang sudah sampai pada arti"darurat". Rasjid Sulaiman, 2013, "Fiqih Islam”, Bandung ; Sinar Baru Algesindo, Hlm. 294. 
Jakarta pada tanggal 22 - 25 Agustus 1990. Berdasarkan amanat Musyawarah Nasional IV Majelis Ulama Indonesia, telah dibentuk kelompok kerja untuk mendirikan bank berbasis non ribawi di Indonesia. Berdasarkan rekomendasi baik dari Lokakarya Majelis Ulama Indonesia tentang Bunga Bank dan Perbankan maupun hasil Musyawarah Nasional IV Majelis Ulama Indonesia sekaligus dengan diundangkannya Undang-Undang Nomor 7 Tahun 1992 tentang perbankan sebagai pengganti Undang-Undang Nomor 14 tahun 1967 tentang Pokok-Pokok Perbankan yang memuat ketentuan dalam pasal 1 angka 12 yaitu diperbolehkannya kegiatan operasional perbankan yang berbasiskan bagi hasil. Kehadiran Bank Syariah yang pertama yaitu PT Bank Muamalat Indonesia pada tahun 1992 merupakan awal sejarah perkembangan bank syariah di Indonesia dimana dalam menjalankan kegiatan operasionalnya berkewajiban untuk memadukan nilai-nilai dan penormaan dalam syariat Islam ke dalam transaksi kegiatan ekonomi yang menuju kesejahteraan bagi masyarakat banyak. ${ }^{8}$ Perbankan syariah dalam melakukan kegiatan operasional perbankan tidak hanya untuk tujuan bisnis semata, yang berupa keuntungan materiil, tetapi juga mengejar kebahagiaan di akhirat. Untuk tujuan itu, Bank Syariah dalam melakukan kegiatan operasional perbankan tidak hanya mendasarkan pada ketentuan perbankan pada umumnya tetapi juga mendasarkan kepada ketentuan syariah. Bank syariah harus patuh pada prinsip-prinsip syariah yang terimplementasikan mulai dari pendirian sampai dengan operasionalnya. ${ }^{9}$

\section{RUMUSAN MASALAH}

Berdasarkan pendahuluan di muka, tulisan ini bermaksud ingin mengungkapkan bagaimana eksistensi ekonomi Islam (studi tentang perkembangan parbankan syariah di Indonesia).

\section{METODOLOGI}

Metodologi yang digunakan dalam penulisan ini adalah studi kepustakaan dengan analisis data kualitatif. Tujuan penulisan ini dimaksudkan untuk menegaskan eksistensi ekonomi Islam melalui perkembangan perbankan syariah di Indonesia, mengingat Indonesia merupakan penganut agama Islam terbesar di dunia berdasarkan hasil sensus Badan Pusat Statistik Tahun 2010, 87,18\% dari 237.641.326 penduduk Indonesia adalah pemeluk Islam, 6,96\% Protestan, 2,9\% Katolik, 1,69\% Hindu, 0,72\% Buddha, 0,05\% Konghucu, 0,13\% Agama lainnya, dan 0,38\% tidak terjawab atau tidak ditanyakan.

\section{PEMBAHASAN}

\section{Eksistensi Ekonomi Islam Melalui Perkembangan Parbankan Syariah Di Indonesia.}

Bidang ekonomi merupakan tempat asal sekularisasi terutama dalam sektor-sektor perokonomian yang sedang dibentuk oleh proses-proses kapitalistik dan industrialisasi ${ }^{10}$. Bank umum didefinisikan sebagai institusi keuangan berorientasi laba, untuk memperoleh laba tersebut bank umum melaksanakan fungsi intermediasi, karena diizinkan mengumpulkan dana dalam bentuk deposito, bank umum tersebut juga sebagai lembaga keuangan depositori, ${ }^{11}$ berbeda dengan bank syariah yang menggunakan mudharabah dan wadiah. Dalam dunia perbankan di Indonesia sejak krisis moneter (krismon) tahun 1997, yang belum kunjung

8 Jundian, 2009, "Pengaturan Hukum Perbankan Syari'ah di Indonesia”, Malang ; UIN-Malang Press, Hlm. 22

9 Muhammad Danang Wahyu, 2014, "Penerapam Prinsip Syariah Dalam Permodalan Bank Syariah", Jurnal Media Hukum, Vol. 21 No. 1, Hlm. 46

10 Industrialisasi adalah suatu fenomena pilihan cara hidup manusia yang membuat manusia itu tidak pernah bertahan pada angka nol akan tetapi dia selalu ingin ditambah dan ditambah terus, dan dia akan sampai ke tak terhingga dan kemudian hilang. Karena plus-plus yang dia capai, maka pasti akan ada yang disebut dalam proposal ini dampak negatip, yaitu minus, minus. Akan tetapi manusia tidak pernah mau di titik nol karena inginnya ditambah-tambah terus. Nadjib, Emha Ainun. 1995. "Agama Sebagai Roh Bagi Industrialisasi". Surakarta : Muhammadiyah University Press. Hlm 191.

11 Syadullah Makmun, 2009, "Menuju Green Economy”, Yogyakarta : Ekonisia, Hlm. 196 
teratasi sampai sekarang, terlihat telah berkembang sistem dan praktek perbankan kapitalistik yang tidak etik karena menekankan pada pengejaran untung sebesar-besarnya. Krisis ekonomi yang sangat parah tersebut, dan hingga kini masih belum pulih, merupakan refleksi buruknya etika bisnis di Indonesia, baik di kalangan pemerintahan maupun swasta, baik di pusat maupun di daerah, serta di segala tingkatan. Di Indonesia, khususnya di lingkungan pelaku ekonomi, keberadaan etika bisnis tampaknya masih merupakan suatu konsep. Menurut I.S Susanto, dimensi etik di kalangan bisnis sangat tipis bahkan terabaikan ${ }^{12}$. Dalam suatu negara yang masyarakatnya beragama, mempunyai ideologi Pancasila dan masih menjunjung nilai moral kondisi tersebut nampak sangat memprihatinkan.

Sejarah telah mencatat perkembangan Perbankan Islam di dunia terbagi dalam empat periode $:^{13}$

a. The esthablishment period (Periode Pendirian)

b. The spread period (Periode Penyebaran)

c. The international recognition period (Periode Pengakuan International)

d. The evaluation period (Periode Evaluasi)

Tabel 1. Perkembangan Perbankan Islamic Tahun 1965-Sekarang

\begin{tabular}{|c|c|c|}
\hline The Period & Date & Characteristics \\
\hline Establishment & $1965-1976$ & $\begin{array}{l}\text { Major activities across the } \\
\text { Muslim word in the area of } \\
\text { research in all fields that } \\
\text { concern Muslim's daily live. } \\
\text { The establishment of Muslim } \\
\text { organization to promote } \\
\text { cooperation and support } \\
\text { among Muslim countries. } \\
\text { The establishment of several } \\
\text { Islamic banks across the } \\
\text { Muslim world. }\end{array}$ \\
\hline The Spread & $1977-2002$ & $\begin{array}{l}\text { Fueled with the sharp } \\
\text { increase in oil prices and } \\
\text { huge wealth in the Middle } \\
\text { East. The establishment of } \\
\text { hundreds of Islamic Banks } \\
\text { across the globe. The } \\
\text { transformation of the } \\
\text { financial system to complete } \\
\text { Islamic banking Iran, } \\
\text { Sudan, and Pakistan. }\end{array}$ \\
\hline The International Recognition & $2003-2009$ & $\begin{array}{l}\text { The globe acceptance of } \\
\text { Islamic Banks by the } \\
\text { western and recognition } \\
\text { american regulators. The } \\
\text { growing interest of } \\
\text { international banks in } \\
\text { western Europe, the United } \\
\text { Stated, and Japan in Islamic } \\
\text { Finance. }\end{array}$ \\
\hline The Evaluation & 2009-present & $\begin{array}{l}\text { The large, healthy gross of } \\
\text { Islamic assets compared to } \\
\text { the large decline in the } \\
\text { conventional bank assets } \\
\text { during the global crisis. } \\
\text { Islamic banks were the least } \\
\text { affected by the global crisis. }\end{array}$ \\
\hline
\end{tabular}

12 I.S Susanto. "Hukum, Etika Politik dan Etika Bisnis”. Kompas. 1 Juni 1995.

13 Mohamed El Tiby Amr, 2011, “ISLAMIC BANKING (How To Manage Risk And Improve Profitability)”, Canada: Wiley Finance, Hlm. 10 
Di Indonesia, telah menjadi tren untuk pergeseran preferensi investasi dari konvensional ke saham Syariah sejak krisis keuangan. Mulai dari krisis keuangan Asia tahun 1997-1998 dan krisis keuangan global 2006-2009. Baru-baru ini, tidak hanya memiliki pasar modal yang berbasis Syariah dikembangkan di negara-negara Muslim, namun juga mulai untuk menarik perhatian di negara-negara non-Muslim. Karena pentingnya pengembangan pasar modal dalam perekonomian, sejumlah studi terkait dengan mengevaluasi kinerja portofolio Islamicand konvensional indeks telah dilakukan di negara-negara maju dan berkembang, salah satunya yaitu hasil perbandingan dengan Malaysia sebagai mitra, Dewi dan Ferdian (2012) menemukan bahwa reksadana syariah Indonesia sedikit mengungguli dalam hal dana alokasi aset dan dana utang selama periode Januari 2006 - April 2009. ${ }^{14} \mathrm{Hal}$ ini dapat tercapai karena Sistem bunga bank digunakan oleh bank konvensional untuk memperoleh keuntungan dari dana yang diinvestasikan melalui pembiayaan kepada nasabah tanpa memperdulikan apakah usaha nasabah tersebut mengalami keuntungan ataukah sebaliknya. Tetapi berbeda dengan sistem dalam bank syariah dalam mencari keuntungan atas dana yang diinvestasikan, bank syariah menerapkan nisbah bagi hasil yaitu dengan membagi keuntungan atau kerugian (Profit and Loss Sharing atau PLS) terhadap produk-produk pembiayaan yang berbasis NUC (Natural Uncertainty Contract) yaitu akad bisnis yang tidak memberikan kepastian pendapatan baik dari segi jumlah Walaupun waktu tetapi berdasarkan keuntungan atau kerugian atas usaha yang dijalankan, seperti mudharabah dan musyarakah. Hal ini diterapkan pada bank syariah karena bank syariah adalah bank yang Semua sistem operasi lainnya tidak boleh bertentangan dengan ajaran Islam yang melarang riba. Di dalam Al-Quran Surah alBaqarah ayat 275 telah dijelaskan bahwa Allah mengharamkan riba dan sebagai gantinya adalah dengan menggunakan prinsip bagi hasil. Dengan prinsiip ini tidak ada pihak yang dirugikan dalam akad tersebut, karena prinsip ini berdasarkan keridhoan kedua pihak yang mengadakan akad. ${ }^{15}$

Secara garis besar, perlu kiranya untuk dikemukakan beberapa hal yang membedakan antara perbankan yang kegiatan operasionalnya didasarkan pada prinsip syariah (perbankan syariah) dengan perbankan yang kegiatan operasionalnya didasarkan pada bunga (perbankan konvensional adalah sebagai berikut $:^{16}$

14 Pranata Nika, Nurzanah. 2015. "Conventional and Islamic Indices in Indonesia: A Comparison on Performance, Volatility, and The Determinants". Journal Indonesian Capital Market Review. Vol 7. No 2. Hlm 115-116.

15 Sucingtyas Siti Aisyah, Latifah Durrotul. 2013. "Analisis Pembiayaan Musyarakah Pada Bank Umum Syariah di Indonesia”. Jurnal Ekonomi dan Bisnis EKOBIS. Vol 15. No 2. Hlm 208-209

16 Jundian, 2009, "Pengaturan Hukum Perbankan Syari'ah di Indonesia”, Malang ; UIN-Malang Press, Hlm. 16 
1. Kegiatan usaha berkarakter bagi hasil dan non bagi hasil

2. Beberapa akad digunakan :

a. Bentuk simpanan (tabungan, giro, dan deposito) dengan akad mudharabah dan wadiah.

b. Bentuk penyaluran dana dengan :

1) Prinsip jual-beli dengan akad mutabahah, istishna atau salam.

2) Prinsip bagi hasil dengan akad mudharabah dan musyarakah.

3) Prinsip sewa menyewa dengan akad ijaah dan ijarah muntahiya bittamlik.

4) Pinjam meminjam dengan akad qardih.

c. Bentuk pelayanan jasa dengan akad wakalah, hawalah, kafalah, dan rahn.

3. Hubungan dengan nasabah dalam tabungan kemitraan

4. Pengawasan kegiatan usaha dilakukan oleh Dewan Pengawas Syariah dan Bank Indonesia

5. Produk atau jasa yang dikeluarkan oleh bank melalui kajian Bank Indonesia dengan mempertimbangkan fatwa DewaN Syariah Nasional.

6. Kegiatan usaha tidak bersifat gharar dan maisir.

7. Kegiatan usaha tidak bersifat Tawazun, yakni meliputi keseimbangan aspek material dan spiritual, aspek privat dan publik, Sektor keuangan dan sektor rill, bisnis dan sosial, dan keseimbangan aspek pemanfaatan dan keadilan.
1. Kegiatan usaha bank berkarakter membungakan uang

2. Beberapa perjanjian yang digunakan:

a. Bentuk simpanan dengan perjanjian penabungan, giro, dan deposito.

b. Bentuk penyaluran dana dengan perjanjian pinjam meminjam/kredit perbankan dan berbagai macam produk derivatifnya.
3. Rentan dalam mewujudkan hubungan kemitraan

4. Pengawasan dilakukan oelh Bank Indonesia

5. Produk atau jasa melalui kajian Bank Indonesia.

6. Dapat menjalankan transaksi yang bersifat spekulatif yang tidak berkaitan secara langsung dengan produktifitas di sektor rill.

7. Kegiatan usaha bersifat mencari keuntungan semata sehingga dapat memarjinalkan sektor rill, sosial, lingkungan hidup dan menimbulkan kemudharatan.

Tabel 3. Perkembangan Perbankan Syariah 2013-2015

\begin{tabular}{llll}
\hline Indikator & $\mathbf{2 0 1 3}$ & $\mathbf{2 0 1 4}$ & $\mathbf{2 0 1 5}$ \\
\hline Jumlah Bank & & & \\
Bank Umum Syariah (BUS) & 11 & 12 & 12 \\
Unit Usaha Syariah (UUS) & 23 & 22 & 22 \\
BPR Syariah (BPRS) & 163 & 161 & 161 \\
Bank Umum Syariah (BUS) & 1.998 & 2.151 & 2.121 \\
Unit Usaha Syariah (UUS) & 590 & 320 & 327 \\
BPR Syariah (BPRS) & 402 & 439 & 433 \\
Jumlah Kantor (total) & 2.990 & 2.910 & 2.881 \\
\hline
\end{tabular}

Sumber : Statistik Perbankan Syariah, Juni 2015 
Pertumbuhan Perbankan Syariah tahun 2014-2015 cenderung mengalami trend penurunan sehingga pertumbuhan menjadi kurang optimal, beberapa faktor penyebab pertumbuhan yang kurang optimal tersebut antara lain ; Pertama, komitmen pemerintah yang masih kurang, Berkaitan dengan regulasi pemerintah yang cenderung membatasi peran serta dari masyarkat dalam upaya untuk memajukan perbankan syariah. Dalam Peraturan Otoritas Jasa Keuangan No. 37/POJK.03/2016 Tentang Rencana Bisnis Bank Perkreditan Rakyat Dan Bank Pembiayaan Rakyat Syariah. Bagi masyarakat yang ingin mendirikan BPR dengan modal inti minimun 6 milyar. Maka orang lebih memilih di sektor rill karena menyerap banyak tenaga kerja. Kedua, Masih kurangnya sosialisasi terkait Perbankan Syariah, Dalam menghadapi persaingan dengan sistem konvensional perlu strategi jitu, yaitu bank syariah perlu merancang loncatan pertumbuhan yang memuaskan (quantum growing). Selama satu tahun yang dilakukan oleh Bank Indonesia berdasar laporan akhir tahun Bank Indonesia 2006, kegiatan sosialisasi oleh Bank Indonesia sepanjang tahun 2006 hanyalah 51 kali. Sebuah upaya yang sangat minim mengingat besarnya jumlah penduduk Indonesia. Idealnya dalam setahun bisa dilakukan minimal 5 juta kali sosialisasi dalam setahun, bukan 51 kali. Semakin bertambahnya jumlah bank syariah di Indonesia juga diharapkan mampu mendorong minat masyarakat untuk lebih openship terhadap keberadaan bank syariah, meskipun kondisi ini tidak sepenuhnya menjamin bahwa masyarakat lebih memilih bank syariah sebagai solusi keuangan dari sistem konvensional yang juga berkembang pesat dan masih dalam posisi likuiditas yang tinggi. Dan Ketiga, Pemahaman masyarakat tentang keuangan syariah menjadi salah satu tolak ukur kebangkitan industri keuangan syariah di Indonesia. Menurut hasil survei nasional literasi dan inklusi keuangan (snlik) otoritas jasa keuangan (ojk) tahun 2016, tingkat pengguna produk dan jasa keuangan syariah di Indonesia baru sebesar 11,06\%. Sedangkan indeks literasi keuangan syariah sebesar 8,11 persen.

Dalam hukum, J.D.Ny Hart mengemukakan adanya 6 konsep hukum mempunyai pengaruh bagi pengembangan kehidupan ekonomi, yaitu sebagai berikut:

a. Prediktabilitas Hukum harus mempunyai kemampuan untuk memberikan gambaran pasti di masa depan mengenai keadaan atau hubungan-hubungan yang dilakukan pada masa sekarang.

b. Faktor pengembangan sistem hukum harus dapat menjadi kekuatan yang memberikan keseimbangan diantara nilai-nilai yang bertentangan di dalam masyarakat, sistem hukum memberikan kesadaran akan keseimbangan dalam usaha usaha negara melakukan Pembangunan Ekonomi.

c. Definisi dan kejernihan tentang status disamping fungsi hukum yang memberikan Prediktabilitas dapat ditambahkan bahwa fungsi hukum juga memberikan ketegasan mengenai status orang-orang dan barang di masyarakat

d. Akomodasi perubahan yang cepat sekali pada hakekatnya akan menyebabkan hilangnya keseimbangan yang lama baik dalam hubungan antara individu maupun kelompok di dalam masyarakat, keadaan ini dengan sendirinya menghendaki dipulihkannya keseimbangan tersebut melalui satu dan lain Jalan titik di sini sistem hukum yang mengatur hubungan antara individu baik secara material maupun formal memberi kesempatan kepada keseimbangan yang yang terganggu itu untuk menyesuaikan diri kepada lingkungan yang baru sebagai akibat perubahan tersebut pemulihan kembali ini dimungkinkan oleh karena didalam kegoncangan ini sistem hukum memberikan tegangan kepastian melalui perumusan perumusan yang jelas dan definitif membuka kesempatan begitu dipulihkannya keadilan melalui prosedur yang tertib dan sebagainya.

e. Kemampuan prosedural pembinaan di bidang hukum acara memungkinkan hukum material itu dapat merealisasikan dirinya dengan baik ke dalam pengertian hukum acara itu termasuk tidak hanya ketentuan-ketentuan hukum perundang-undangan melainkan juga semua prosedur penyelesaian yang disetujui oleh para pihak yang bersengketa 
misalnya bentuk-bentuk arbitrasi konsiliasi dan sebagainya semua lembaga tersebut Anaknya dapat bekerja dengan efisien apabila diharapkan bahwa kehidupan ekonomi itu ingin mencapai tingkatannya yang maksimum.

f. Kodifikasi dari pada tujuan-tujuan perundang-undangan dapat dilihat sebagai suatu kodifikasi tujuan serta maksud sebagaimana dikehendaki oleh negara di bidang ekonomi misalnya kita akan dapat menjumpai tujuan-tujuan itu seperti dirumuskan di dalam beberapa perundang-undangan yang secara langsung atau tidak langsung mempunyai pengaruh terhadap bidang perekonomian. Dalam proses berdirinya perbankan syariah, tidaklah cukup hanya dengan fatwa Dewan Syariah Nasional yang kemudian di adopsi oleh Bank Indonesia dalam bentuk Peraturan Bank Indonesia. Akan tetapi, diperlukan peraturan yang prediktabilitas hukumnya harus mempunyai kemampuan untuk memberikan gambaran pasti di masa depan mengenai keadaan atau hubungan-hubungan yang dilakukan pada masa sekarang. Berdasarkan hal tersebut, akhirnya produk hukum Undang-Undang Nomor 21 Tahun 2008 tentang Perbankan Syariah lahir sebagai jawaban atas prediktabilitas hukum. Berikut bagan 1 perkembangan hukum perbankan di Indonesia dalam peraturan perundang-undangan :

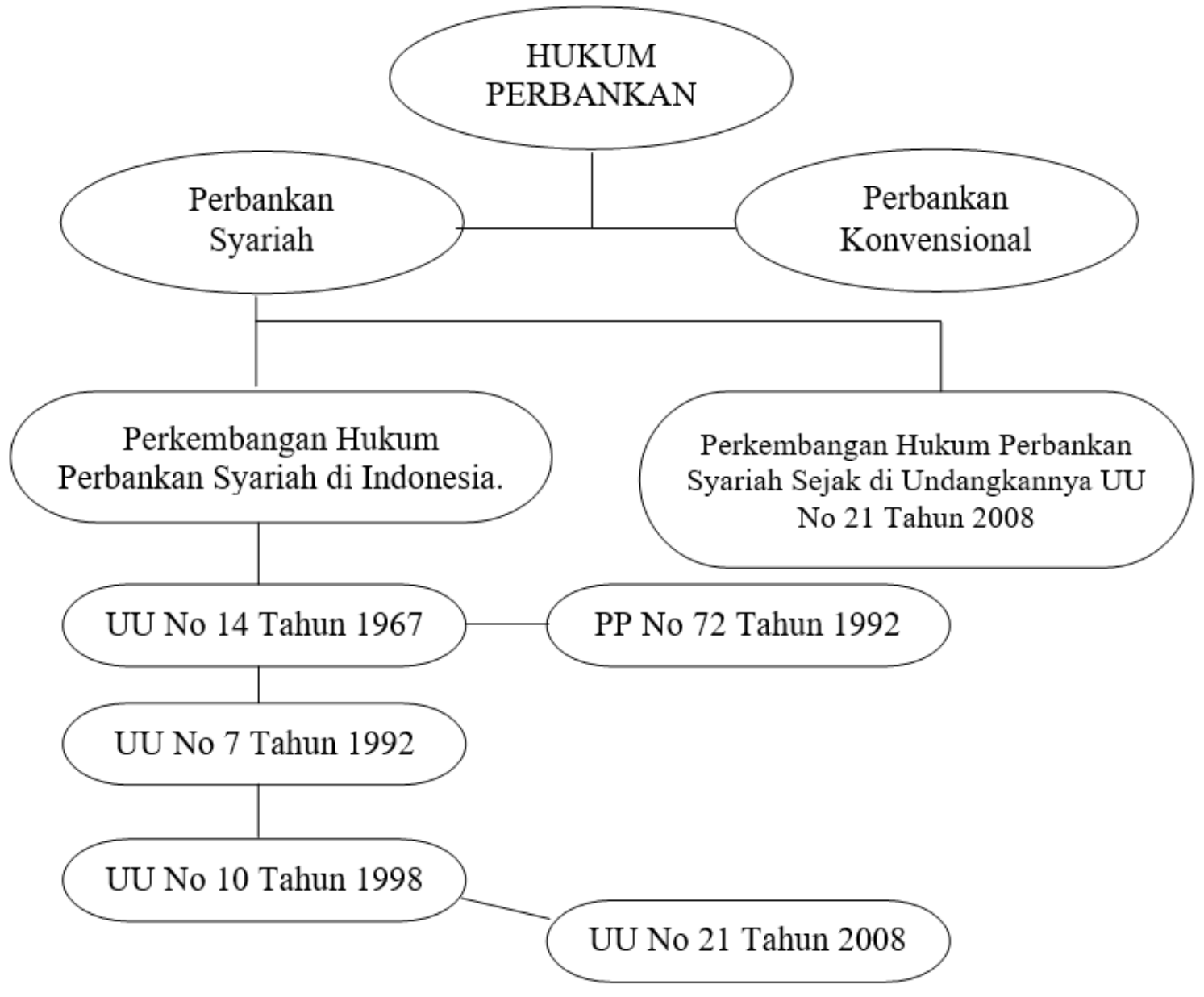

Berdasarkan bagan diatas, perkembangan perbankan di Indonesia sudah dimulai sejak lama, akan tetapi belum menyinggung prinsip-prinsip syariah hingga dimasa-masa akhir orde baru. Dalam Pasal 1 UU No. 7 Tahun 1992 jo UU No. 10 Tahun 1998 tentang perbankan (selanjutnya disebut UU Perbankan) jo PP No. 72 Tahun 1992 menyatakan bahwa bank adalah badan usaha yang menghimpun dana dari masyarakat dalam bentuk simpanan dan menyalurkan kepada masyarkat dalam bentuk kredit dan/atau dalam bentuk-bentuk lainnya dalam rangka meningkatkan taraf hidup orang banyak. Dari pengertian hukum perbankan 
tersebut dapat disimpulkan bahwa hukum perbankan merupakan serangkaian kententuan hukum positif yang mengatur segala seuatu yang menyangkut tentang bank, kelembagaan, kegiatan usaha, serta cara dan proses pelaksanaan kegiatan tersebut. Kehadiran Perbankan syariah menjadi pelengkap sistem perbankan konvensional yang telah ada sebelumnya, ditandai dengan dikeluarkannya Undang-undang No. 7 Tahun 1992 tentang Perbankan, yang secara eksplisit memperbolehkan bank menjalankan usahanya berdasarkan sistem bagi hasil, walaupun dalam UU ini tidak ada ketegasan pemberlakuan prinsip syariah.

Penggunaan istilah bagi hasil dalam perundang-undangan pada saat itu belum mencakup secara tepat pengertan perbankan syariah yang memiliki cakupam lebih luas. Melalui Lembaran Negara Republik Indonesia No. 182 tanggal 10 November 1998 disahkan Undang-Undang No. 10 Tahun 1998 tentang Perbankan yang memuat perubahan atas UU No. 7 Tahun 1992 tentang Perbankan. Dalam UU ini sudah menunjukan dimulainya era sistem perbankan ganda yang diharapkan akan mempercepat perkembangan Perbankan Syariah di Indonesia. Jika dalam peraturan sebelumnya mengatakan bahwa kegiatan usaha-usaha hanya berdasarakan prinsip bagi hasil saja. Namun sekarang mulai ditinggalkan, karena telah lahir Undang-Undang Nomor 21 Tahun 2008 tentang Perbankan Syariah yang mana telah meliki cakupan yang luas untuk mengelola keuangan masyarakat, sebagaimana dalam pasal 1 angka 1 Undang-Undang Nomor 21 Tahun 2008 tentang Perbankan Syariah berbunyi bahwa perbankan syariah adalah segala sesuatu yang menyangkut tentang Bank Syariah dan Unit Usaha Syariah, mencakup kelembagaan, kegiatan usaha, serta cara dalam melaksanakan kegiatan usahanya. Hal ini menegaskan bahwa segala sesuatu yang menyangkut Bank Syariah dan Unit Usaha Syariah, mencakup kelembagaan, kegiatan usaha, maupun prosesnya dilakukan berdasarkan UU yang baru ini.

Tujuan bank syariah sebagaimana diatur dalam Undang-Undang Nomor 21 tahun 2008 tentang Perbankan Syariah yang disahkan pada 16 Juli 2008 adalah pembangunan nasional Indonesia untuk mencapai terciptanya masyarakat adil dan makmur berdasarkan demokrasi ekonomi yang berlandaskan nilai keadilan, kebersamaan, dan kemanfaatan yang sesuai dengan prinsip syariah.

Bagan 2. Landasan Perbankan Syariah di Indonesia

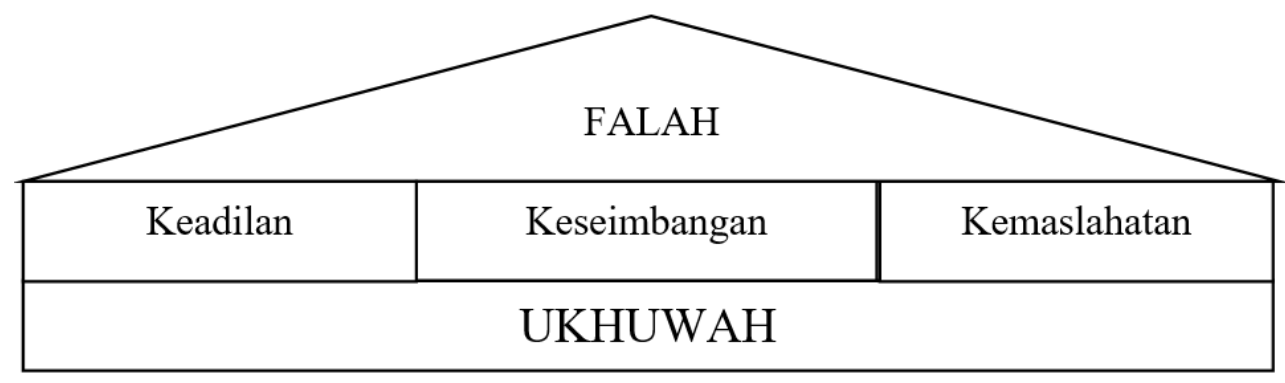

\begin{tabular}{|c|c|}
\hline Syariah & Akhlak \\
\hline \multicolumn{2}{|c|}{ AKIDAH } \\
\hline
\end{tabular}

Selaras dengan tujuan tersebut. Prinsip-prinsip Bank Syariah yang harus diterapkan dalam mendukung eksistensi Bank Syariah, meliputi: ${ }^{17}$

a. Prinsip Al-Ta'awun

Merupakan prinsip untuk saling membantu dan bekerja sama. Dalam hal ini Allah Swt

17 Muhammad Danang Wahyu, 2014,"Penerapan Prinsip Syariah Dalam Permodalan Bank Syariah”, Jurnal Media Hukum, Vol. 21, No. 1, Hlm. 46-47. 
telah memerintahkan kepada manusia untuk berbuat saling tolong menolong dalam berbuat keadilan dan takwa. Sebaliknya, Allah Swt melarang manusia saling tolong menolong dalam hal berbuat dosa dan pelanggaran, sebagaimana firman Allah dalam QS. Al-Maidah: $2 .^{18}$

b. Prinsip Menghidar Al-Ikhtinaz

Prinsip ini sejalan dengan fungsi uang, yaitu tidak membiarkan uang menganggur dan tidak berputar dalam transaksi yang bermanfaat bagi masyarakat umum. Dalam pandangan Islam, uang adalah flow concept, oleh karena itu harus berputar dalam perekonomian. Semakin cepat uang berputar dalam perekonomian, maka akan semakin tinggi tingkat perndapatan masyarakat dan semakin baik perekonomiannya. Prinsip ini mendasarkan pada firman Allah Swt, yang tercantum dalam QS. An_Nisaa': 29. ${ }^{19}$

Dalam perbankan Syariah dilarang keras untuk melakukan transaksi apabila terdapat halhal sebagai berikut:

a. Gharar, yaitu adanya unsur-unsur ketidakpastian atau tipu muslihat dalam transaksi.

b. Masyir, yaitu unsur judi yang transaksinya bersifat spekulatif yang dapat menimbulkan kerugian satu pihak dan keuntungan bagi piha lain.

c. Riba, yaitu transaksi yang menggunakan sistem bunga.

\section{KESIMPULAN}

Peranan agama di Indonesia memiliki andil yang sangat penting dalam kehidupan bermasyarakat. Hal ini dinyatakan secara jelas dalam pancasila sebagai ideologi bangsa Indonesia sila pertama "Ketuhanan Yang Maha Esa". Salah satunya adalah peran perbankan syariah yang memiliki tujuan pembangunan nasional Indonesia untuk mencapai terciptanya masyarakat adil dan makmur berdasarkan demokrasi ekonomi yang berlandaskan nilai keadilan, kebersamaan, dan kemanfaatan yang sesuai dengan prinsip syariah. Kondisi Perbankan di Indonesia mengalami tren untuk pergeseran preferensi investasi dari konvensional ke saham Syariah sejak krisis keuangan. Mulai dari krisis keuangan Asia tahun 1997-1998 dan krisis keuangan global 2006-2009. Kehadiran Perbankan syariah menjadi pelengkap sistem perbankan konvensional yang telah ada sebelumnya. Perkembangan Bank Syariah di Indonesia sampai pada Tahun 2015 telah mengalami tren penurunan dikarenakan komitmen pemerintah masih dilihat kurang, minimnya sosialisasi tentang perbankan syariah serta tingkat literasi dan inklusi masih kurang. Untuk menghadapi hal tersebut perlu kiranya dilakukan upaya yang dapat meningkatkan pertumbuhan ekonomi Islam dan Perbankan Syariah pada khususnya melalui regulasi yang tidak membatasi peran serta masyarakat, masifikasi gerakan pengenalan Perbankan Syariah dan membangun kepercayaan terhadap masyarakat dengan mengedepankan ketaatan terhadap Syariah. Sampai dengan Tahun 2015 terdapat 12 (dua belas) Bank Umum Syariah (BUS), 22 Unit Usaha Syariah (UUS) dan 161 Bank Pembiayaan Rakyat Syariah (BPRS). Secara keseluruhan jaringan kantor Bank Umum Syariah dan Unit Usaha Syariah berjumlah 2.881 Kantor.

18 QS. Al-Maidah ayat 2, yang artinya "Hai orang-orangyang beriman, janganlah kamu melanggar Syi'ar-Syi'ar Allah, dan jangan mealnggar kehormatan bulan-bulan haram, jangan (mengganggu) binatang-binatang hadnya, dan binatang-binatang qalaa-id, dan jangan (pula) mengganggu orang-orang yang menjunjung Baitullah sedang mereka mencari karunia dan keridhaan dari Tuhannya dan apabila kamu telah menyelesaikan ibadah haji, maka bolehlah berburu, dan jangan sekali kebencian(mu) kepada sesuatu kaum karena mereka menghalang-halangi kamu dari masjidilharam, mendorongmu berbuat aniaya (kepada mereka) dan tolong menolonglah kamu dalam (mengerjakan) kebajikan dan takwa, dan jangan tolong menolong dalam berbuat dosa dan pelanggaran. Dan takutlah kamu kepada Allah, sesungguhnya Allah amat berat siksaNya"

19 QS. An_Nisaa' ayat 29, yang artinya "Hai orang-orang yang beriman, janganlah kamu saling memakan harta sesamamu dengan jalan yang batil, kecuali dengan jalan perniagaan yang berlaku dengan suka sama suka di antara kamu, janganlah kaтu membunuh dirimu; sesungguhnya Allah adalah Maha Penyayang Kepadamu”, 


\section{DAFTAR PUSTAKA}

Asifudin Ahmad Janan. 2004, "Etos Kerja Islami”, Surakarta ; Muhammadiyah Press. Ikatan Bankir Indonesia, 2015, "Strategi Bisnis Bank Syariah”, Jakarta : PT Gramedia Pustaka Utama.

I.S Susanto."Hukum, Etika Politik dan Etika Bisnis”. Kompas. 1 Juni 1995

Jundian, 2009, "Pengaturan Hukum Perbankan Syari'ah di Indonesia”, Malang ; UIN-Malang Press.

Kementerian koordinator bidang perekonomian, 2013, (online), (http://www.ekon.go.id/ekliping/ view/paket-kebijakan-ekonomi-xiv.2862.html, diakses pada tanggal 20 November 2016)

Kadafi Muhammad, Iskandar Muda. 2013. "Penerapan Konsep Hukum Pembangunan Ekonomi Dalam Upaya Pencegahan Eksploitasi Pekerja Alih Daya, Kajian Putusan Mk Nomor 27/ Puu-Ix/2011". Jurnal Yudisial. Vol 6. No 1

Mohamed El Tiby Amr, 2011, “ ISLAMIC BANKING (How To Manage Risk And Improve Profitability)", Canada : Wiley Finance

Muhammad Danang Wahyu, 2014, "Penerapam Prinsip Syariah Dalam Permodalan Bank Syariah”, Jurnal Media Hukum, Vol. 21 No. 1

Nadjib, EmhaAinun. 1995. “Agama Sebagai Roh Bagi Industrialisasi”. Surakarta: Muhammadiyah University Press. Hlm 191

Nurhisam Luqman, 2016,"Kepatuhan Syariah (Sharia Compliance) Dalam Industri Keuangan Syariah”, Jurnal Hukum IUS QUIA IUSTUM, Vol. 23 No.1

Pranata Nika, Nurzanah. 2015. "Conventional and Islamic Indices in Indonesia : A omparison on Performance, Volatility, and The Determinants". Journal Indonesian Capital Market Review. Vol 7. No 2

Rasjid Sulaiman, 2013, “Fiqih Islam”, Bandung; Sinar Baru Algesindo

Sucingtyas Siti Aisyah, Latifah Durrotul. 2013. "Analisis Pembiayaan Musyarakah Pada Bank Umum Syariah di Indonesia”. Jurnal Ekonomi dan Bisnis EKOBIS. Vol 15. No 2. Hlm 208-209

Syadullah Makmun, 2009, “Menuju Green Economy”, Yogyakarta : Ekonisia 